\title{
THINK PAIR SHARE (TPS) TECHNIQUE FOR IMPROVING STUDENTS READING COMPREHENSION OF NARATIVE TEXT IN THE SEVENTH GRADE STUDENTS OF SMPN 3 KLARI KARAWANG
}

\author{
Anisa Yulianti' ${ }^{1}$, Hesti Arum Lestari' ${ }^{2}$ Yana $^{3}$ \\ ${ }^{1}$ IKIP Siliwangi \\ 2 IKIP Siliwangi \\ ${ }^{3}$ IKIP Siliwangi \\ ${ }^{1}$ anisayulianti79@gmail.com, ${ }^{2}$ hestiarum997@gmail.com, ${ }^{3}$ yanaenglish.edu@ gmail.com
}

\begin{abstract}
This research used Classroom Action Research. Think Pair Share can be trusted to help students comprehend reading skill. The population of the research were the students of SMPN 3 Klari Karawang in Academic years 2017-2018. The total population of the students in this academic year are 280 students. The number of sample were 30 students. The data was gathered from the test and observation. After being implementated of Think Pair Share activities in every cycle, the students' reading score were getting better. We can see from the result of students' average score Cycle I 63.47 and Cycle II 79.67. In conclusion, the Technique of Think Pair Share can improve learners' reading comprehension.
\end{abstract}

Keywords: Think Pair Share, Reading Comprehension, CAR (Classroom Active Research)

\section{INTRODUCTION}

English language is spoken by most people in the world, by using English we can communicate between the people with different country, and it is also the language of computers program that help us communicate with persons around the world via internet technology and e-mail. Regarding the problem formerly stated, Harmer in (Apsari, 2007) claims that getting learners to read English texts is a prominent part of the English teacher's occupation because of four reasons. First, many learners are eager to be able to read the texts of English for present study, for further study, future career or simply pleasure. Second, reading is very useful for acquisition of language. Third, texts of reading provide good models of English writing concerning construction of phrases, sentences, paragraph, and discourse. Finally, excellent reading texts may introduce fabulous topics, stimulate discussion, excite creative responses, and provide fascinating lessons. Based on the description mentioned above, it might be deduced that reading material is very important in the teaching of reading.

In teaching learning of language there are four skills, namely listening, speaking, reading and writing. Harmer (1998: 70) as cited in Parmawati and Yugafiati (2017) states that, reading is an incredibly active occupation. Reading is an important part of learning English, by reading we can improve our vocabulary and writing skill and when students have a good habit reading, they will have a lot of knowledge. But several English for learners find it difficult to understand what they read and they don not know the ways to become a good reader. 


\section{Volume 2, No. 6, November 2019 pp 830-837

According to William in (Cahyono and Widiati,2011;49) reading could be divided into two types; namely initial reading and reading comprehension. The first of the two is an effort which is made by those who cannot read to learn reading (like how to read the alphabet and letters combination or simple words), whereas reading comprehension is an activity aimed at understanding the message of a certain text. The teaching of reading as a foreign language in Indonesia might be in general included in the instruction of reading comprehension. This is because it aims at improving the skills of learners, who have been able to read in their first language and in EFL, in understanding the meaning of a written text.

Reading is useful for some purposes, perhaps it require for carrier, study and for pleasure. Reading not only embraced some skills and language components but also can enlarge the knowledge to get more information. In reading class, some of the students feel bored with these activities; beside they don "et know about the meaning, they also don "et have interesting to read. Students ${ }^{e e}$ problem can be solved by giving information to students that reading is very important which has aims to: (a) introduce and develop reading skills which are useful outside the classroom (b) introduce or practice language (Knight \& Lindsay, 2006). By knowing the aims of reading, students will be motivated to love the reading activities. Besides, the problem faced by students it can be about their background knowledge of the topic selected in reading or the vocabulary building. (Gebhard, 2006) states that students" ability to comprehend the content of reading, material depends in part on their knowledge about the topic of the reading selection. The vocabulary building problem, it is not just beginners who need lots of vocabulary. All students need to work constantly on building vocabulary and teacher can show students how to do this on their own. EFL learners are not understanding the English text maybe it caused by the difficult vocabulary. Comprehension means understanding a text fully meaning and relevance, comprehension is often difficult to teach directly, however because it encompasses so much and relies on so many different skill, (Afrilianti, 2014) As a teacher should be solve this problem, maybe by creating a confidence classroom by using the best strategies, perhaps it will help them to comprehend what they read. In encyclopedia of educational, written, reading comprehension is the ability of reading text, processing it and understanding its meaning. their traits and skill influenced the ability of individual to understand text, one of which is making inferences ability.

Related to statement above, the researchers uses TPS technique which might be applied in reading. TPS offers some benefits and it can build positive interdependence with their partner because in doing TPS, the students are able to learn from each other, Mundriyah and Parmawati (2016). So, the researchers is interested in improving reading comprehension of the students by using think pair share in the instructional process, because the great techniques can make the process of learning effective and make students have the achievement improvement. Thinkpair-share is one of the techniques that can be used by the English teachers in learning reading comprehension. Think-Pair-Share tecnique is one kinds of cooperative learning method which is useful for students not only to comprehend the English text but also the students can learn the sociality of life, because this technique requires the students to discuss, share and respect of their friend. Based on Goor \& Schween, 1993 in (Afrilianti, 2014) five common formats used for cooperative learning activities are: STAD, Think-pair-share, jigsaw, Team accelerated instruction, and group investigation. Think-Pair-Share; the students first try to answer a question or learn material by themselves, then discuss their taught and understandings with their 
partners, and finally share with their whole group or the class based on Kagan, 1992, in (Afrilianti, 2014).

(Kagan, 2009) mentioned that there are five steps in TPS technique, namely organizing learners into pairs, posing the topic or a question, giving students time to think, asking students to discuss with their partners and sharing their ideas with each other, calling on several students to share ideas with their friends. (Kagan, 2009) also mentioned some advantages of think-pairshare technique, when students are given time to think, students' abilities increase, students are actively involved in thinking becomes more focused when it is discussed with a partner, students think more critically after they are given the opportunity to discuss and reflect on the topic of learning, no specific materials are needed for this learning technique, it becomes easier to apply in learning.

\section{METHOD}

This research used Classroom Action Research (CAR), This is perceived as the appropriate method by the researchers, because the focus of the researchers is to improve the students' reading comprehensions the real teaching and learning process, classroom action research was conducted in a certain step. The general process of conducting this research was briefly introduced as a four-stages procedures according to (Cohen, Manion, \& Morrison, 2002) (1) Planning; (2) action (i.e. implementing the plan); (3) Observating, (evaluation and selfevaluation); (4) Critical and self-critical reflection on the results of points 13 and making decisions for the next cycle of action research (Reflecting). There are four steps of typical action research model, they are divided into certain cycles of action starting from stage 1(Planning), stage 2 (action), stage 3 (observing), and stage 4 (reflecting).

This study was conducted on grade 7th students of a state junior high school in Karawang consisting of 30 students as research subjects, the target score stated in school KKM (Kriteria Ketuntasan Minimal), which is 75 as the minimum score for English subject at the this school.

The researchers also used three data collection tools to obtain the data, namely:

a. Test

The test consists of 30 multiple choice items related to the narrative text. Student score is included in the table score to analyze. This is a technique to gain the mean score. Students may achieve success indicators meaning that the teacher could help students improve their reading comprehension utilizing TPS. The researchers calculating the result of students reading test as follows:

$$
\text { Score }=\frac{\text { Students' }^{\text {Correct Answer }}}{\text { Total Number of Items }} \times 100
$$

(Thesis, n.d.)

The researchers described the analysis of data taken from the results of the student's reading test. The mean score of each student is calculated using the formula below:

$m=\frac{\sum x}{N}$

832 | Think Pair Share (Tps) Technique For Improving Students Reading Comprehension Of Narative Text In The Seventh Grade Students Of Smpn 3 Klari Karawang 
Note: $\mathrm{m}=$ the students mean score

$\sum x=$ the sum of students score

$\mathrm{N}=$ the number of students

(Mertler, 2009)

The mean score was classified into the following table:

Table 1. Creiteria Mean Score

\begin{tabular}{cc}
\hline Range & Qualification \\
\hline $96-100$ & Excellent \\
\hline $86-95$ & Very Good \\
\hline $76-85$ & Good \\
\hline $66-75$ & Fairly Good \\
\hline $56-65$ & Fair \\
\hline $46-55$ & Poor \\
\hline $0-45$ & Very Poor
\end{tabular}

Pendikbud in ( Thesis, n.d.)

b. Observation sheet

Observation sheet is applied to observe students within teaching activities. Such an observation sheet is used as well to obtain the data of student activity during the process of teaching and learning by using think pair share technique.

c. Field notes

Field notes are notes that are made when learning activities are exercised. The researchers analyzed the data taken from the result of the student worksheet.

\section{RESULTS AND DISCUSSION}

\section{Results}

This research was conducted in two cycles. The researchers applied reading comprehension in narrative text material using the think pair share technique, the teacher conducted the research in the first cycle based on the problems in the seven grade of SMPN 3 Klari Karawang, among others: students had difficulty identifying the generic structure of the narrative text, students had difficulties in comprehending the information in narrative texts. After collecting the student tasks, the researchers calculates the students' scores in order to get the mean score. The results of the first cycle are not really good, the mean score in the first cycle is 63.47. It means that the researchers must be better in the next cycle because the aim of the researchers is to reach the mean score of 75 . The results of the first cycle can be seen from the table below: 
Table 2. Students score in Cycle 1

\begin{tabular}{cc}
\hline Students & Score \\
\hline Students 1 & 73 \\
\hline Students 2 & 70 \\
\hline Students 3 & 60 \\
\hline Students 4 & 73 \\
\hline Students 5 & 53 \\
\hline Students 6 & 57 \\
\hline Students 7 & 80 \\
\hline Students 8 & 33 \\
\hline Students 9 & 53 \\
\hline Students 10 & 73 \\
\hline Students 11 & 83 \\
\hline Students 12 & 57 \\
\hline Students 13 & 77 \\
\hline Students 14 & 73 \\
\hline Students 15 & 47 \\
\hline Students 16 & 43 \\
\hline Students 17 & 83 \\
\hline Students 18 & 63 \\
\hline Students 19 & 50 \\
\hline Students 20 & 60 \\
\hline Students 21 & 60 \\
\hline Students 22 & 63 \\
\hline Students 23 & 63 \\
\hline Students 24 & 63 \\
\hline Students 25 & 67 \\
\hline Students 26 & 67 \\
\hline Students 27 & 73 \\
\hline Students 28 & 70 \\
\hline Students 29 & 70 \\
\hline Students 30 & 47 \\
\hline Total & 1904 \\
\hline
\end{tabular}

$$
\begin{aligned}
m=\frac{\sum x}{N} & \\
& =\frac{1904}{30} \\
& =63.47
\end{aligned}
$$

Regarding the first cycle, the problem that must be solved in the second cycle is that students are still confused in determining the generic structure of the narrative text, students are still difficult to find information in the narrative text, students are still less motivated to read narrative texts, students are not familiar with think-pair-share technique. Based on the problem 834 | Think Pair Share (Tps) Technique For Improving Students Reading Comprehension Of Narative Text In The Seventh Grade Students Of Smpn 3 Klari Karawang 
above, the researchers conducted the second cycle. The researchers explains think-pair-share technique in narrative text so students are motivated and accustomed to the learning process. The results are good because it can be seen from the number of students increase in their scores and the mean score of students is 79.67. The results of the second cycle can be seen from the table below:

Table 3. Students score in Cycle II

\begin{tabular}{ll}
\hline Students & Score \\
\hline Students 1 & 80 \\
\hline Students 2 & 83 \\
\hline Students 3 & 77 \\
\hline Students 4 & 77 \\
\hline Students 5 & 73 \\
\hline Students 6 & 83 \\
\hline Students 7 & 80 \\
\hline Students 8 & 77 \\
\hline Students 9 & 77 \\
\hline Students 10 & 77 \\
\hline Students 11 & 90 \\
\hline Students 12 & 77 \\
\hline Students 13 & 80 \\
\hline Students 14 & 77 \\
\hline Students 15 & 80 \\
\hline Students 16 & 80 \\
\hline Students 17 & 93 \\
\hline Students 18 & 80 \\
\hline Students 19 & 80 \\
\hline Students 20 & 77 \\
\hline Students 21 & 77 \\
\hline Students 22 & 80 \\
\hline Students 23 & 87 \\
\hline Students 24 & 77 \\
\hline Students 25 & 80 \\
\hline Students 26 & 77 \\
\hline Students 27 & 80 \\
\hline Students 28 & 77 \\
\hline Students 29 & 80 \\
\hline Students 30 & 77 \\
\hline Total & 2390 \\
\hline
\end{tabular}




$$
\begin{aligned}
m=\frac{\sum x}{N} & \\
& =\frac{2390}{30} \\
& =79.67
\end{aligned}
$$

Based on the findings, the learning process in the second cycle is better than the first cycle. Students' mean scores increased in reading comprehension of narrative text. The cycle can be stopped because the average score shows more than $75 \mathrm{KKM}$ values. That means the research has succeeded and the cycle can be stopped.

\section{Discussion}

This classroom action research is carried out in two cycles. There are planning, action, observation and reflection in each cycle. Students faced difficulties in reading comprehension of narrative text including students find it difficult to understand detailed information, students face difficulties in determining the generic structure contained in narrative text, and students face difficulties in determining the main ideas in narrative text. In the first cycle, students face difficulties in determining the generic structure and detailed information contained in narrative text. In the second cycle, researchers actively monitor student discussions in each group, students' first answer their own questions then students pair up with friends to get information or find the most correct answers. Students show enthusiasm with good teamwork and students become more active seen, they enjoy the learning recount text using think-pair-share technique. Students can complete the task given by researchers, researchers also provide opportunities for students to exchange thoughts during the learning process. The researchers stops the class action because the data shows the achievement score has been successful. The findings show that the average value of students at the first cycle is 63.47. It is qualified "Fair". That means researchers must prepare better for the next cycle. And at the second cycle the students get average score is 79.67 it is qualified is "good".

Percentage of achievement score for each student was presented as follows: Based on the score of KKM (Kriteria Ketuntasan Minimum) in English subject at SMPN 3 Klari Karawang 100\% of children graduated from the KKM score. Think-pair-share technique makes students active in learning and students can learn in pairs. Students can also share knowledge with their group friends through class discussions In conclusion, the research findings are in accordance with what the researchers expected. Reading comprehension in narrative text increases using the think-pair-share technique. In the teaching and learning process, students are not only seen reading to answer questions but they show interest and motivation to learn in reading comprehension of narrative text.

\section{CONCLUSION}

Reading comprehension of the seven grade of SMPN 3 Klari Karawang has increased with the use of think-pair-share techniques. The findings indicate that the mean score of students in reading comprehension is 63,47 and 79.67 . Students work in pairs and groups. Think-pair-share technique also allows students to express their thoughts, opinions, and information obtained 
from narrative texts to their friends. At the first cycle, there were no good results, the results began to appear when the cycle was carried out two times. In conclusion think-pair-share (TPS) technique is proven to be able to help students improve their reading comprehension in narrative text.

\section{ACKNOWLEDGMENTS}

Bismillahirrahmanirrahim, Alhamdulillahirabbil'alamin, thanks to Allah SWT who has enabled to finish this paper. Peace and solutions are always for Rasulullah SAW. Thanks to SMP N 3 Klari Karawang, family, friend and lecturer Mr.Dasep Suprijadi M.Pd and Mr.Yana M.Hum during finishing this paper.

\section{REFERENCES}

Afrilianti, A. (2014). The Effectiveness Of Using Tps (Think-Pair-Share) Strategy To Improve Students Reading Comprehension Of The First Grade At Mtsn Aryojeding Rejotangan Tulungagung In Academic Year 2013/2014.

Apsari, Y. (2007). The Use Of Authentic Materials In Teaching Reading, 88-94.

Cahyono, B. Y. (N.D.). The Teaching Of Efl Reading In The Indonesian Context: The State Of The Art, 36-58.

Cohen, L., Manion, L., \& Morrison, K. (2002). Research Methods In Education. Routledge.

Gebhard, J. G. (2006). Teaching English As A Foreign Or Second Language: A Teacher SelfDevelopment And Methodology Guide. University Of Michigan Press.

Kagan, S. (2009). Kagan's Cooperative Learning. San Clemente: Kagan Publishing.

Knight, P., \& Lindsay, C. (2006). Learning And Teaching English: A Course For Teachers. Oxford University Press.

Mertler, C. A. (2009). Action Research: Teachers As Researchers In The Classroom. Sage.

Mundriyah, M., \& Parmawati, A. (2016). Using Think-Pair-Share (Tps) To Improve Students'writing Creativity (A Classroom Action Research In The Second Semester Students Of Stkip Siliwangi Bandung). P2m Stkip Siliwangi, 3(2), 84-91.

Parmawati, A., \& Yugafiati, R. (2017). Using Authentic Material To Improve Students'reading Interest (A Classroom Action Research In The Second Semester Students Of Stkip Siliwangi Bandung). Eltin Journal, Journal Of English Language Teaching In Indonesia, $5(1), 1-8$.

Thesis, A. (N.D.). The Effectiveness Of Directed Reading Activity Method In Teaching Reading To The Second Year Students Of Sma Muhammadiyah 6 Makassar English Education Department, (20401106029), 1-75. 